\title{
Milk yield and composition of Katahdin and Pelibuey ewes in tropical conditions
}

\author{
A.J. Chay-Canul' ${ }^{1}$, G.M. Parra-Bracamonte ${ }^{2,6}$, N. Lopez-Villalobos ${ }^{3}$, J.B. Herrera-Ojeda², \\ J.G. Magaña-Monforte ${ }^{4}$, I.N. Peniche-González ${ }^{4}$, J. Herrera-Camacho ${ }^{5}$ and R. García-Herrera ${ }^{1}$ \\ 1 Juarez Autonomous University of Tabasco, Academic Division of Agricultural Sciences, \\ Km. 25 Villahermosa-Teapa Road, Teapa, Tabasco, México \\ ${ }^{2}$ National Polytechnic Institute (IPN), Genomics Biotechnology Center, \\ Blvd. Del Maestro SN, Narciso Mendoza, Reynosa, 88710, Tamaulipas, Mexico \\ ${ }^{3}$ Massey University, School of Agriculture and Environment. Private Bag 11-222 Palmerston North, 4442, New Zealand \\ ${ }^{4}$ Autonomous University of Yucatan, Faculty of Veterinary Medicine and Zootechnics \\ Km. 15.5 Mérida-Xmatkuil Road, Mérida, 97100, Yucatan, Mexico \\ ${ }^{5}$ Michoacan University of Saint Nicholas of Hidalgo, Agricultural and Forestry Research Institute, Km 9.5 Morelia - Zinapécuaro \\ Road, Tarimbaro, 58880, Michoacan, Mexico
}

KEY WORDS: milking performance, milk solids, lactation, litter size, tropics, sheep

Received: 15 September 2020

Revised: 8 October 2020

Accepted: 19 November 2020

${ }^{6}$ Corresponding author:

e-mail: gparra@ipn.mx

\begin{abstract}
Pelibuey and Katahdin are two the most extensively used hair sheep breeds in tropical regions characterized by high temperatures and humidity. Lactation influences profitability of sheep in dairy and non-dairy production systems. Therefore, the aim of this study was to evaluate the effect of breed and litter size (LS) on milk yield and milk composition of Pelibuey $(n=28)$ and Katahdin $(n=21)$ ewes reared under tropical conditions of Mexico. Milk, fat, protein and lactose yields, fat and energy-corrected milk, and fat, protein and lactose percentages were measured for seven weeks. Body weight (BW) of each ewe was measured weekly. Breed effects were significant $(P<0.001)$ favouring Katahdin breed on all yield traits. Ewes rearing two lambs had higher yields $(P<0.01)$ for all traits than ewes rearing one lamb. Fat percentage and BW were significantly $(P<0.05)$ affected by a triple interaction effect of Breed $x$ LS $x$ Week. So, important differences in milk yield and composition among breeds and LS were shown and might be considered in order to improve profitability of sheep production systems under tropical conditions.
\end{abstract}

\section{Introduction}

In all production systems, milk yield of the dam is a determinant of good performance and early growth of young animals (Morgan et al., 2016). During the first weeks of lamb life, growth depends completely on the ewe milk, until it can eat solid feeds such like concentrates and pasture. Increased ewe productivity, which is determined by litter sizes and lamb growth rates, can improve the profitability of lamb production systems.
In some studies the effect of quantity and quality of milk supply during pre-weaning period on the growth and feed conversion efficiency of lambs after weaning was reported (Danso et al., 2016). The estimation of milk yield contributes a valuable information needed to implement management strategies both for ewes and their lamb as the milk yield influences weaning weight and variations in milking ability among breeds and genetic groups available in tropical areas (Peniche-Gonzalez et al., 2015). 
Pelibuey and Katahdin breeds, are currently extensively used in different regions of Mexico. Pelibuey is the most popular sheep breed as it exhibits non-seasonal reproduction characteristics, rusticity, prolificacy and high tolerance to parasites (Aguilar-Martínez et al., 2017). Similarly, Katahdin, a breed created by crossbreeding from different Caribbean tropical breeds with British breeds (Wildeus, 1997), has been extensively used as purebred sheep and also as an animal for crossbreeding purposes and dispersed throughout all regions of Mexico since its introduction from USA. Unfortunately, there is a limited number of studies reporting the milk yield and milk composition of these breeds under tropical conditions of Mexico. This information might be useful to design feeding systems aimed to sustain the nutrient requirements for ewes needed to obtain optimal pre-weaning lamb growth and body recovering of the ewe after weaning. So, the objective of the study was to evaluate milk composition and milk production indicators of Pelibuey and Katahdin ewes rearing one or two lambs.

\section{Material and methods}

\section{Experimental design}

Animals were managed in accordance to the guidelines and regulations for ethical animal experimentation of Academic Division of Agricultural Sciences of Juarez Autonomous University of Tabasco, and approved as a project: PFI: UJAT-DACA-2015IA-02. The animals were kept at the 'El Rodeo' farm, located at $17^{\circ} 84^{\prime} \mathrm{N}$ latitude and $92^{\circ} 81^{\prime} \mathrm{W}$ longitude, Tabasco State, Mexico, with an a verage temperature of $28{ }^{\circ} \mathrm{C}$ and $63 \mathrm{~mm}$ of rainfall during the experimental months, with extremes of relative humidity between 54-95\%. In the study 2-3 year-old Pelibuey $(\mathrm{n}=28)$ and Katahdin $(\mathrm{n}=21)$ ewes lambing during March 2016 were used. Animal mean body weight (BW) was $45.43 \pm 6.80 \mathrm{~kg}$.

\section{Management of animals}

After lambing, each ewe and their offspring were maintained and managed under a feedlot system in individual pens for 49 days, with free access to feed and water. Ewes were dewormed with $0.2 \mathrm{mg} / \mathrm{kg}$ BW of Cydectin NF${ }^{\circledR}$ (Pfizer, New York, NY, USA). Animals were fed star grass hay (Cynodon nlemfuemsis), soybean meal, ground maize sugarcane molasses and minerals, with an estimated metabolizable energy of $12 \mathrm{MJ} / \mathrm{kg}$ dry matter (DM) and $15 \%$ crude protein (CP) (AFRC, 1993). Each week animals BW was measured and the amount of feed offered to each ewe was adjusted weekly according to BW. The diet was formulated according to AFRC guidelines (AFRC 1993) for ewes with $45 \mathrm{~kg}$ mean BW producing $1.74 \mathrm{~kg}$ milk/day with $7 \%$ fat and $4.5 \% \mathrm{CP}$.

Lamb milk consumption was determined every week by the weigh-suckle-weight (WSW) method as described previously by Peniche-González et al. (2015). Lamb BW (kg) were measured every week from the first week of the experiment until day 49 (7 weeks). The WSW method involved a weekly lamb separation from the dam starting at 3:00, lasting for $3 \mathrm{~h}$, and then suckling for $10 \mathrm{~min}$ at 6:00. Next, lambs were again separated from ewes after suckling (at 9:00, 12:00, 15:00 and 18:00) and put in pens that allowed sight and smell contact with their dams but avoided suckling. The difference between pre- and post-suckling weight was defined as milk consumption. Daily milk yield (MY, kg) of ewes at the week of measurement was calculated by the total of the estimations recorded during the $12 \mathrm{~h}$ period and multiplying by two (Peniche-González et al., 2015).

\section{Milk composition}

Ewes were hand-milked every week (the day after estimation of MY) in the morning after previous injection of $3 \mathrm{IU}$ of Oxitocin (Pisa, Mexico) and samples of $100 \mathrm{ml}$ were used for milk composition analysis. Analyses of fat, protein and lactose percentage were performed by duplicate using an automatic milk analyser (Lactoscan LS-60, Milkotronic Ltd., Nova Zagora, Bulgaria). The equipment was calibrated for fat by the Gerber method and for protein by a total nitrogen determination, according to the Dumas method using a LECO CNS-2000 series 3740 analyser (LECO Corp. St. Joseph, MI, USA). Daily yields of fat (FY), protein (PY) and lactose (LY) were calculated by multiplying the MY by corresponding percentages. Energy-corrected milk yield (ECM, kg) fwas calculated according to formula of Sjaunja et al. (1990):

$$
\begin{gathered}
\mathrm{ECM}=\mathrm{MY} \times\{[(38.3 \times \mathrm{FY})+(24.2 \times \mathrm{PY})+ \\
783.2] / 3140\} .
\end{gathered}
$$

\section{Statistical analyses}

All dependent variables were analysed using a mixed linear model for repeated measures, with the following model:

$$
y_{i j k l}=\mu+B_{i}+L S_{k}+W_{l}+B L_{i k}+\beta x_{i j k}+\alpha_{j}+\varepsilon_{i j k l} \text { (a) }
$$

where: $y_{i j k l}$ - evaluated trait, $\mu$ - overall mean, $B_{i}$-fixed effect of the $i_{\text {th }}$ breed (Pelibuey or Katahdin), $L S_{k}$ - fixed effect of the $k_{t h}$ litter size (single or twin), $W_{l}$ - fixed effect of $1^{\text {th }}$ week of lactation $(1,2, \ldots, 7), B L_{i k}-$ interaction between breed and 
litter size, an alternative model replacing described interaction by Breed $\times$ LS $\times$ Week of lactation was also fitted, $\beta$ - regression coefficient of initial trait $x_{i j k l}$ affecting the record $y_{i j k l}, \alpha_{j}$-random effect of the $j^{\text {th }}$ ewe, and $\varepsilon_{i j k l}$ random error associated with the $y_{i j k l}$ record.

It was assumed that:

$$
\begin{aligned}
& E\left(y_{i k l}\right)=\mu+B_{i}+W_{k}+L_{l}+B W S_{i k l}+\beta x_{i j k l}, \\
& \operatorname{Var}\left(\alpha_{j}\right)=\sigma_{d}^{2} \text { and } \operatorname{Cov}\left(\varepsilon_{i j k l,} \varepsilon_{i^{\prime} j^{\prime} k^{\prime} l^{\prime}}\right)=\boldsymbol{R}
\end{aligned}
$$

Based on the Akaike Information Criterion a compound symmetry covariance structure was selected as the best structure to model the matrix $\boldsymbol{R}$ to account for repeated measures on the same animal. Least-squares means for fixed effects were obtained and used for multiple mean comparisons with a Bonferroni adjustment. All statistical procedures were performed using the statistical computer package SAS 9.3 (SAS Institute Inc., Cary, NC, USA).

\section{Results}

Least-squares means for BW and milk traits for breeds and LS and their interaction are presented in Table 1. Effects of breed and LS were significant for all daily yield traits $(P<0.01)$. Conversely, no significant effect of these factors on BW and milk composition traits was present. Interaction between breed and LS was not significant for any of the traits $(P>0.05)$. Katahdin ewes rearing one and two lambs yielded 16 and $23 \mathrm{~g}$ more protein and fat per day of

Table 1. Least-squares means ( \pm SE) for body weight and milk yield and composition traits of Pelibuey and Katahdin ewes rearing single and

\begin{tabular}{|c|c|c|c|c|c|c|c|c|}
\hline \multirow{2}{*}{ Trait } & \multicolumn{2}{|l|}{ Breed } & \multicolumn{2}{|l|}{ Litter size } & \multicolumn{2}{|l|}{ Pelibuey } & \multicolumn{2}{|l|}{ Katahdin } \\
\hline & pelibuey & katahdin & singleton & twin & singleton & twin & singleton & twin \\
\hline Body weight, kg & $46.5 \pm 1.27$ & $44.4 \pm 1.49$ & $44.9 \pm 1.14$ & $46.0 \pm 1.59$ & $44.5 \pm 1.52$ & $48.6 \pm 2.04$ & $45.43 \pm 1.72$ & $43.4 \pm 2.43$ \\
\hline \multicolumn{9}{|l|}{ Daily yields } \\
\hline milk, $\mathrm{kg}$ & $1.44 \pm 0.05^{b}$ & $1.77 \pm 0.06^{\mathrm{a}}$ & $1.30 \pm 0.04^{b}$ & $1.91 \pm 0.06^{a}$ & $1.19 \pm 0.06^{z}$ & $1.69 \pm 0.08^{x}$ & $1.42 \pm 0.07^{y}$ & $2.13 \pm 0.10^{\mathrm{w}}$ \\
\hline fat, $\mathrm{g}$ & $84.1 \pm 4.68^{b}$ & $107.2 \pm 5.21^{a}$ & $82.4 \pm 4.07^{b}$ & $108.9 \pm 5.65^{a}$ & $76.9 \pm 5.53^{y}$ & $91.4 \pm 7.29^{x}$ & $87.9 \pm 5.95^{x}$ & $126.5 \pm 8.53^{w}$ \\
\hline protein, $\mathrm{g}$ & $73.1 \pm 2.92^{b}$ & $89.2 \pm 3.29^{a}$ & $66.9 \pm 2.56^{b}$ & $95.4 \pm 3.56^{\mathrm{a}}$ & $60.0 \pm 3.46^{z}$ & $86.2 \pm 4.59^{x}$ & $73.8 \pm 3.77^{y}$ & $104.8 \pm 5.39^{\mathrm{w}}$ \\
\hline lactose, $\mathrm{g}$ & $71.5 \pm 2.80^{\mathrm{b}}$ & $87.8 \pm 3.16^{a}$ & $65.9 \pm 2.47^{b}$ & $93.5 \pm 3.42^{\mathrm{a}}$ & $59.2 \pm 3.32^{y}$ & $83.8 \pm 4.41^{x}$ & $72.6 \pm 3.62^{x}$ & $103.1 \pm 5.18^{w}$ \\
\hline $\mathrm{ECM}, \mathrm{kg}$ & $1.93 \pm 0.08^{b}$ & $2.40 \pm 0.10^{\mathrm{a}}$ & $1.84 \pm 0.07^{b}$ & $2.49 \pm 0.10^{a}$ & $1.68 \pm 0.10^{y}$ & $2.18 \pm 0.13^{x}$ & $2.00 \pm 0.11^{x}$ & $2.80 \pm 0.15^{w}$ \\
\hline \multicolumn{9}{|l|}{ Composition, \% } \\
\hline fat & $6.0 \pm 0.21$ & $6.3 \pm 0.25$ & $6.4 \pm 0.19$ & $5.9 \pm 0.27$ & $6.5 \pm 0.26$ & $5.5 \pm 0.34$ & $6.2 \pm 0.29$ & $6.3 \pm 0.41$ \\
\hline protein & $5.0 \pm 0.31$ & $5.1 \pm 0.04$ & $5.0 \pm 0.03$ & $5.1 \pm 0.04$ & $4.9 \pm 0.04$ & $5.1 \pm 0.05$ & $5.1 \pm 0.04$ & $5.1 \pm 0.06$ \\
\hline lactose & $4.9 \pm 0.04$ & $5.0 \pm 0.04$ & $4.9 \pm 0.03$ & $5.0 \pm 0.05$ & $4.9 \pm 0.05$ & $4.9 \pm 0.06$ & $5.0 \pm 0.05$ & $5.0 \pm 0.07$ \\
\hline
\end{tabular}
twin lambs under tropical conditions of Mexico.

ECM - energy corrected milk, SE - standard error, ${ }^{\text {ab }}$ - means with different superscripts within one effect are significantly different at $P<0.05$, wyxz - means with different superscripts are significantly different at $P<0.05$
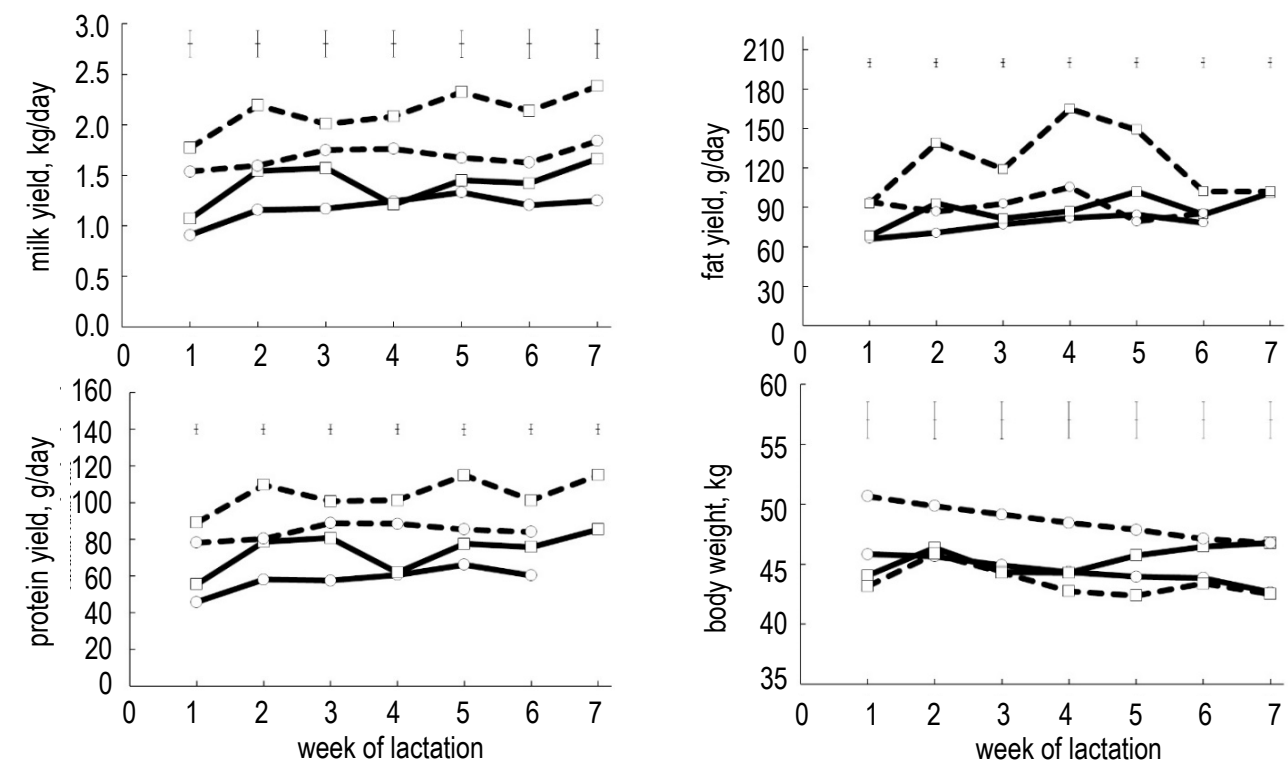

Figure 1. Daily yields of milk, fat and protein, and body weight of Pelibuey (०) and Katahdin ( $\square$ ) ewes by singleton $(\rightarrow)$ and twin litter size $(\boldsymbol{C})$ during seven weeks of lactation. Means are presented as pooled standard error. 
lactation, respectively, in comparison to Pelibuey ewes. Ewes rearing two lambs produced from 25 to $32 \%$ more $(P<0.05)$ milk and component yields than ewes rearing one lamb (Table 1). The interaction between breed and LS was not significant. Katahdin ewes rearing two lambs produced the highest yields of milk and milk constituents resulting in the highest yield of ECM. Katahdin ewes rearing one lamb produced similar yields of milk, milk components and ECM in comparison to Pelibuey ewes rearing two lambs (Table 1).
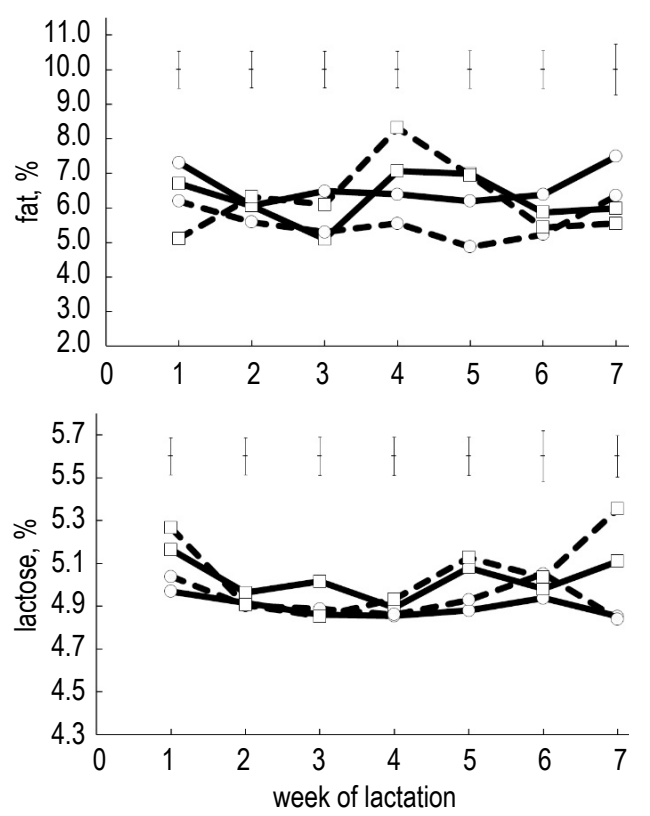

In the present study, Katahdin ewes were characterised by a higher milk performance and milk constituents yield in comparison to Pelibuey ewes but had similar fat and protein percentages during the 7-week experiment. In contrast to dairy sheep breeds characterised by long lactating periods, nondairy breeds and hair sheep breeds, such like Katahdin and Pelibuey, during the shorter lactating period provide optimal nutrition for their lambs. However, Katahdin ewes produced higher amount of milk and milk constituents than Pelibuey ewes with similar protein and fat percentage.
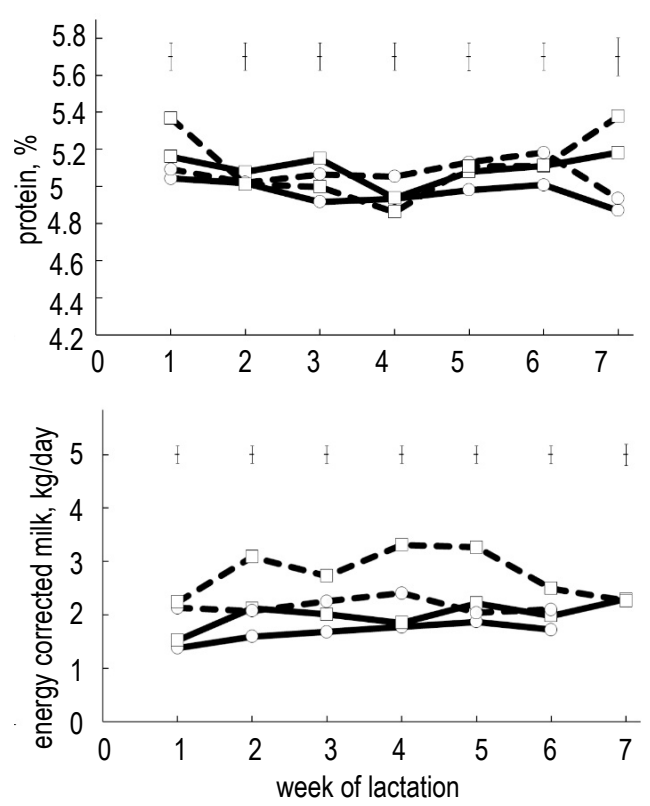

Figure 2. Percentages of fat, protein and lactose, and daily yield of fat-corrected milk of Pelibuey ( $\circ)$ and Katahdin ( $\square$ ) ewes by single $(\square)$ and twin litter sizes ( - ) during seven weeks of lactation. Means are presented as pooled standard error.

\section{Discussion}

Breed effect is one of the most important variations affecting milk yield and milk composition. The milk performance of the hair sheep breeds considered in this study was presented only in few studies. Burgos-Gonzáles et al. (2018), reported an average of $1.381 \mathrm{milk} /$ day of Katahdin ewes managed in a subtropical environment, slightly lower than the mean value estimated in this study (1.77 $\mathrm{kg} /$ day). Average milk production of Pelibuey and Pelibuey crosses in Cuba was lower than the mean value of milk production of Pelibuey ewes used in our study (Pavón et al., 1987). Similarly, lower averages (around $1.1 \mathrm{~kg} /$ day) of milk production were reported by Peniche-González et al. (2015), estimated in a Pelibuey $\times$ Katahdin group of ewes in Yucatan, Mexico.
In the present study, due to tropical conditions the experimental design assumed an early weaning plan (separation of lambs from ewes 60 days after lambing) in order to avoid extreme loss of corporal condition of the ewe (García and Oliva, 2016). Comparing the performance of the two breeds used in the study, it can be seen that early weaning was more profitable for Pelibuey ewes that comparatively showed more weight loss. The triple interaction Breed $\mathrm{x}$ LS $\mathrm{x}$ Week was significant since Pelibuey ewes rearing twin lambs at the beginning of the study were the heaviest, however a pronounced decline of their weight was observed through the 7-week experimental period. On the other hand, it was revealed that Katahdin ewes can achieve good production levels and maintain the body weight for a longer time than Pelibuey ewes. In the economic point of view, longer weaning 
periods ensure healthy and heavy lambs at weaning (García and Oliva, 2016), which positively influences the final producer income.

Another positive financial aspect for producers can be seen in milking levels presented in our study. Although not conventionally for tropical region of Mexico, apparently longer lactations and production were observed. Castellanos and Valencia (1982) evaluated milk production and composition of Pelibuey ewes from Yucatan and proposed a dual-purpose management for milk and cheese production using milk solid composition and large proportion of fat, and better acceptability than cow milk products. As for international markets milk solids are important, this potential ability needs to be taken into consideration, especially by the producers focused on harvesting.

On the other hand, it was indicated that, at the beginning of lactation and regardless of breed, ewes rearing twin lambs were heavier, had higher daily MY with similar percentages of fat and protein than animals rearing only one lamb. Ewes rearing twin lambs produced more accumulated MY than ewes rearing one lamb. Similarly to the results of Morgan et al. (2016), MY peak in ewes rearing two lambs was around second and fourth week of lactation.

The ewe MY performance is directly related to the suckling stimulus of litter size, determining the subsequent full secretion trough the course of lactation (Rosales et al., 2018). It was previously reported that the intensity of suckling has a hormonal basis present since the postpartum, through the exposure of oestrogen, progesterone, placental lactogen and oxytocin stimulating mammogenesis and lactogenesis of the ewe, which as a consequence can be observed as high placental weight and foetal growth (Selvaggi et al., 2016). Additionally, Marnet and Negrão (2000) indicated that two or more lambs suckle for a longer time than one lamb, and therefore longer teat stimulation increases the release of oxytocin and prolactin secretions in dams.

The number of lambs born from the one ewe influences the quality of milk - higher milk fat percentages were noted in ewes rearing twins than in those rearing one lamb (Snowder and Glimp, 1991). Also, tropical conditions can influence percentage of milk total solids: the more lambs are reared by the ewe the more total solids are present in the milk (Macedo et al., 2012).

These findings support the high potential of the ewe mammary gland which is necessary to obtain satisfactory lamb growth, so important in sheep production systems used in tropics. It was previously found that MY and composition explained most of variations in the Romney twin lambs growth during the first 42 days of suckling (Danso et al., 2016), suggesting that the selection of ewes with higher MY could maximize the lamb growth before weaning. Therefore, the consideration of MY and composition potentials of some breeds can influence the profitability of productive systems under humid tropical conditions. This strategy could be accompanied with an appropriate feeding of ewes resulting in an optimal pre-weaning lamb growth and immediate recovery of ewe post-weaning.

\section{Conclusions}

In humid tropical conditions lactating Katahdin ewes had higher milk yield and better production performance than Pelibuey ones. However, the milk composition between these two breeds was similar. Ewes rearing twin lambs had higher milk yields, milk components and energy-corrected milk indices. Early weaning could be a recommended milking management for Pelibuey ewes; only when postweaning lamb feeding and health management is improved to ensure high survival rate, optimal lamb growth post weaning, and body weight recovering of the ewe.

\section{Acknowledgements}

The research was supported by the 'Programme for Research Promotion' (PFI: UJAT-DACA-2015IA-02): 'Ewe/lamb energetic efficiency of hair sheep'. Authors are very grateful to dr. Jose Manuel Piña Gutiérrez who provided the facilities of Rancho 'El Rodeo'. We also thank Maritza Avendaño Rodríguez for her assistance.

\section{References}

AFRC, 1993. Energy and Protein Requirements of Ruminants. CAB International. Wallingford (UK)

Aguilar-Martínez C.U., Berruecos-Villalobos J.M., Espinoza-Gutiérrez B., Segura-Correa J.C., Valencia-Méndez J., Roldán-Roldán A., 2017. Origin, history and current situation of pelibuey sheep in Mexico. Trop. Subtrop. Agroecosystems 20, 429-439

Burgos-Gonzáles C., Huerta-Aparicio M., Aguirre V., Vázquez R., Orihuela A., Pedernera M., 2018. Short communication: milk production and lamb development in Saint Croix and Katahdin hair sheep breeds (Ovis aries). Trop. Anim. Health Prod. 50, 683-687, https://doi.org/10.1007/s11250-017-1448-8

Castellanos R.A., Valencia Z.M., 1982. Quantitative and qualitative study of milk production of the Pelibuey sheep. Trop. Anim. Health Prod. 7, 232-240 
Danso A.S., Morel P.C.H., Kenyon P.R., Blair H.T., 2016. Relationships between prenatal ewe traits, milk production, and preweaning performance of twin lambs. J. Anim. Sci. 94, 3527-3539, https://doi.org/10.2527/jas.2016-0337

García O.I.A., Oliva H.J., 2016. Weaning age, crucial moment that determines growing efficiency in the growing and lamb survival. Kuxulkab 22, 13-18

Macedo R.J., Arredondo V., Fernando G., Aguilar M., Prado O., Rodríguez R., 2012. Effect of supplemental yeast culture and physiological factors on colostrum and milk composition of Pelibuey ewes. Trop. Anim. Health Prod. 44, 349-354, https:// doi.org/10.1007/s11250-011-0028-6

Marnet P.G., Negrão J.A., 2000. The effect of a mixed-management system on the release of oxytocin, prolactin, and cortisol in ewes during suckling and machine milking. Reprod. Nutr. Dev. 40, 271-281, https://doi.org/10.1051/rnd:2000131

Morgan J.E., Fogarty A.N.M., Nielsen B., Gilmour A.R., 2016. Milk yield and milk composition from grazing primiparous nondairy crossbred ewes. Aust. J. Agric. Res. 57, 377-387, https://doi.org/10.1071/AR05180

Pavón M., Fuentes J.L., Lima T., Albuernes R., Efremov A., Perón N., 1987. Study of milk production of Pelibuey, Pelibuey $x$ Suffolk and Pelibuey $x$ Corriedale ewe and lamb production from birth to weaning. (In Spanish). Rev. Cub. Reprod. Anim. 13, 39-49

Peniche-González I., Sarmiento F.L., Santos R.R., 2015. Estimation of milk production in hair ewes by two methods of measurement. (In Spanish). Rev. MVZ Córdoba. 20, 4629-4635, https://doi.org/10.21897/rmvz.66
Rosales C.A., Ferguson M.B., Macleay C.A., Briegel J.R., Wood D.A., Martin G.B., Bencini R., Thompson A.N., 2018. Milk production and composition, and progeny performance in young ewes with high merit for rapid growth and muscle and fat accumulation. Animal 12, 1-8, https://doi.org/10.1017/ S1751731118000307

Selvaggi M., D’Alessandro A.G., Dario C., 2016 Environmental and genetic factors affecting milk yield and quality in three Italian sheep breeds J. Dairy Res. 84, 1-5, https://doi.org/10.1017/ S0022029916000765

Sjaunja L.O., Baevre L., Junkkarinen L., Pedersen J., Setälä J., 1991. A Nordic proposal for an energy corrected milk (ECM) formula. In: A. Gaillon, B. Chabert (Editors). Performance recording of animals: state of the art 1990; Proceedings of the $27^{\text {th }}$ biennial session of the International Committee for Animal Recording. Wageningen Pers, Paris (France). pp. 156-157

Snowder G.D., Glimp H.A., 1991. Influence of breed, number of suckling lambs and stage of lactation on ewe milk production and lamb growth under range conditions. J. Anim. Sci. 69 , 923-930, https://doi.org/10.2527/1991.693923x

Wildeus S., 1997. Hair sheep genetic resources and their contribution to diversified small ruminant production in the United States. J. Anim. Sci. 75, 630-640, https://doi.org/10.2527/1997.753630x 